\title{
An Analysis of the Formation of Property Rights Underlying Tortious Interference with Contracts and Other Economic Relations
}

Interference with contract, interference with prospective advantage, and other economic torts have a long history. Under Roman law, the head of a household could bring an action for injuries to members of his household; ${ }^{1}$ a similar action reported by Bracton $^{2}$ was limited during the fifteenth century to an action by a master for loss of his servant's services. ${ }^{3}$ In response to the loss of workers caused by the plague, an action was created by the Statute of Labourers, ${ }^{4}$ which provided that the enticing away of another man's servants would be grounds for imprisonment.

The modern history of interference torts begins with the celebrated case of Lumley $v$. Gye. ${ }^{5}$ The Queen's Bench found that where the defendant maliciously procures a party to breach a valid contract to give her services to the plaintiff, the plaintiff obligee may recover in tort. ${ }^{6}$ Temperton $v$. Russell ${ }^{7}$ extended that liability to encompass interference with contracts not involving personal services, as well as to interference with mere economic expectancies. ${ }^{8}$

Although courts disagree in some important respects as to the exact boundaries of liability for tortious interference, ${ }^{9}$ there is now

Sayre, Inducing Breach of Contract, 36 HARv. L. REv. 663, 663 (1923).

22 H. Bracton, ON the Laws and Customs of England fol. 116, at 326 (S. Thorne ed. 1968).

${ }^{3}$ Sayre, supra note 1, at 665 (citing Y.B. 11 Hen. 4, fol. 47, pl. 21 (1410)).

$123 \mathrm{Edw} .3$, ch.2 (1349).

s 2 El. \& Bl. 216, 118 Eng. Rep. 749 (Q.B. 1853).

Id. at 224-25, 118 Eng. Rep. at 752-53.

7 [1893] 1 Q.B. 715.

- See infra text following note 120 .

- There are two principal areas of uncertainty. First, although some mental state is required for all forms of interference liability, courts have not yet settled on a firm standard. Most jurisdictions find mere negligence insufficient. See W. Prosser, HandBooK of THE LAW of TorTs § 129, at 938 (4th ed. 1971); Note, Negligent Interference with Economic Expectancy: The Case for Recovery, 16 STAN. L. REv. 664, 664 \& n.3 (1964). But see J'aire Corp. v. Gregory, 24 Cal. 3d 799, 598 P.2d 60, 157 Cal. Rptr. 407 (1979) (court allowed recovery for the interference caused to plaintiff's restaurant trade by defendant's negligent performance of a construction contract with the plaintiff's lessor). Even knowledge of the existence of a 
widespread acceptance of the general rules of interference liability. Where the interest disturbed is a contract, even one that is voidable or terminable at will, intentional interference is prima facie actionable; ${ }^{10}$ where the interest is only an expectancy, intentional interference is again actionable, yet any legitimate commercial motive of the interferor can serve as an affirmative defense." These bare bones of the structure of liability-causation, a mental state more culpable than simple negligence, ${ }^{12}$ and privilege for commercially motivated interference-have been secure for nearly one hundred years in England ${ }^{13}$ and for almost as long in the United States. ${ }^{14}$

In contrast to general judicial acceptance of the tort, American

contract will not always be sufficient to allow recovery where the defendant's primary objective in interfering with the contract was not to interfere. See Restatement (Second) or TORTS § 766 comment j (1979); W. ProsszR, supra, § 129, at 941-42. In general, the tort is predicated on the defendant's malice, defined as intent to interfere without justification. $W$. Prosser, supra, § 129, at 942; see Restatement (Second) of Torts § 766 (1979).

Second, courts have not yet agreed on the proper scope of the defense of privilege or justification. Interference because of a disinterested desire to protect the obligor, see Said $\mathrm{v}$. Butt, [1920] 3 K.B. 497, in the name of public morals, see Brimelow v. Casson, [1924] $1 \mathrm{Ch}$. 302 (preventing prostitution); Legris v. Marcotte, 129 Ill. App. 67 (1906) (preventing spread of typhus), or by giving advice to breach, see W. Prosser, supra, $\S 129$, at 944 n.6, is generally not actionable, depending on the interferor's motive. Interference for the purpose of furthering the interferor's economic advantage, on the other hand, involves the court in balancing the interferor's and society's interest in free competition against the interest of the party interfered with and of society in the sanctity of contract and other economic relations. See generally Restatement (Second) of ToRTs § 762 comment g (1979).

10 See Restatement (Second) of ToRTs § 766 (1979).

11 See id. $\$ \$ 767$ comment $f, 768$ (competition gives privilege to interfere with expectancies, not with contracts), 769; W. Prosser, supra note 9, § 130, at 954-62.

${ }^{12}$ Restatement (Second) of Torts \$ 766C (1979).

13 The English law has been largely settled since Temperton v. Russell, [1893] 1 Q.B. 715 , was decided in 1893. See RzSTATzMENT (Second) of TorTs $\S 766$ B (1979). Some disagreement has persisted. For example, in Allen v. Flood, 1898 A.C. 1 (H.L. 1897), the defendant iron-workers' union coerced the plaintiff into ceasing to deal with a rival union under threat of a strike by the defendants. Although several judges, most notably Lord Herschell, criticized the reasoning in Temperton to the extent that it supported the proposition that malice alone was actionable, none suggested that Temperton was wrongly decided. (For a full discussion of the case, see infra notes 136-39 and accompanying text.) Four years later, in Quinn v. Leathem, 1901 A.C. 495 (H.L.), the House of Lords reaffirmed the liability of an intentional interferor with an expectancy. The court upheld liability where the primary intent was to injure. Id. at 512 (opinion of Lord Shand). Although some of the opinions attempt to distinguish Allen on the basis of an absence of conspiracy, most, particularly that of Lord Shand, advance an analysis similar to this comment's, namely, that interference with an expectancy in which the interferor is not directly interested is actionable. Id.; see infra notes 115-16 and accompanying text. Whereas the defendants in Allen were interested in doing the ironwork performed by their rivals, the defendants in Quinn were not seeking the business of the plaintiff whose expectancy they disrupted, but merely the advancement of their union.

14 W. Prosser, supra note $9, \S 129$, at 930 . 
commentators have long regarded it as lacking independent theoretical justification. ${ }^{15}$ They argue that interference with contracts and economic expectancies should not give rise to liability where the means of interference are not tortious in their own right, possibly excepting interference done purely for spite. ${ }^{16}$ This comment will present a theoretical justification for interference liability. It will first examine recent scholarship concerning economic torts, focusing on current analyses of the property rights underlying the torts. It will then analyze those property rights in light of the cases involving animals ferae naturae, which are the principal source of the common law of the acquisition of property. Finally, it will apply the fruits of the analysis of the wild animal cases to a number of well-known interference cases and argue that an obligee or a party expecting to enter into contract has a property right in the pursuit of expected performance free from interference by third parties.

\section{Recent ScholarshiP}

Recent scholarly commentary on interference torts, like recent torts scholarship in general, falls into two camps: economic-utilitarian and corrective justice. The former analyzes liability rules in terms of maximizing the wealth of society as a whole ${ }^{17}$ the latter predicates liability on the infringement of some protected property interest of the individual plaintiff. ${ }^{18}$ This comment accepts as its starting point the corrective justice account of tort law and will concern itself principally with the criticism that a plaintiff whose contract or expectancy has been interfered with has suffered no harm to any property interest good against the world.

Is See, e.g., Wigmore, The Boycott and Kindred Practices As Ground For Damages, 21 AM. L. REv. 509, 521-22 (1887) (no liability for interference by lawful means); cf. Sayre, supra note 1, at 702-03 (no liability for interference with contracts except where interferor procures breach deliberately; no liability for interference with expectancies).

16 See, e.g., Perlman, Interference with Contract and Other Economic Expectancies: $A$ Clash of Tort and Contract Theory, 49 U. CHr. L. REv. 61, 94-97 (1982).

17 See generally R. Posner, The Economics of Justice (1981).

18 See, e.g., Epstein, Intentional Harms, 4 J. Legal Stud. 391, $441-42$ (1975) [hereinafter cited as Intentional Harms]. But see Epstein, Nuisance Law: Corrective Justice and Its Utilitarian Constraints, $8 \mathrm{~J}$. LEgaL. STUd. 49 (1979) [hereinafter cited as Nuisance Law], and Epstein, The Principles of Environmental Protection: The Case of Superfund, 2 Cato J. 9 (1982) [hereinafter cited as Superfund], where Epstein argues that the remedies available under a strict liability regime must be modified, as they must in any legal theory, to take into account the social costs of liability for de minimis harms and exact but unreliable legal rules. 


\section{A. Economic Criticism of Interference Torts}

A complete critique of the normative criticism of interference torts made by economic analysts must await another day. Economic criticism of interference torts, however, suffers shortcomings as a positive matter, as can be seen in the arguments of Professors Rizzo and Perlman.

Professor Rizzo's analysis limits interference liability to those situations where it is socially beneficial. In a recent article, ${ }^{19}$ he argues that the negligent interruption of input or output of some commodity often causes social loss rather than a mere transfer of gain from one producer to another ${ }^{20}$ Rizzo then notes that a party physically injured by an interferor's negligence who is unable to perform contractual obligations may sue the interferor for indemnity for the contract damage owed to the injured party's obligee; society thus concentrates causes of action in those who have suffered physical injury. ${ }^{21}$ Recovery for economic harms is allowed where socially beneficial, i.e., where the costs of channeling losses through the party suffering physical harm plus the expected costs of litigation are outweighed by the value of allowing recovery. ${ }^{22}$

The chief problem with Rizzo's analysis as a positive matter is the starting point for Professor Perlman: the breach of a contract, unlike the commission of a tort, is usually the signal of social gain, as resources are reallocated away from the breached contract to a more socially valuable end. ${ }^{23}$ This occurs, for example, whenever the obligor of a contract is made an offer that benefits him more than the sum of the benefits to him and the obligee of the prior contract, for then the obligor can idemnify the prior obligee for the benefit of his bargain and still benefit from breaking the contract. ${ }^{24}$ As a positive matter, therefore, Rizzo's theory does not account for the broad class of cases where interference liability discourages wealth-increasing transactions.

Perlman's analysis is also inadequate as a positive theory, however. After noting that interference liability frequently discourages efficient breaches of contracts, ${ }^{25}$ Perlman argues that liability

10 Rizzo, A Theory of Economic Loss in the Law of Torts, 11 J. Legal Stud. 281, 28691 (1982).

10 Id. at $286-91$.

11 Id. at $283-84$.

12 Id.

2s Perlman, supra note 16 , at $82-83$.

24 See R. Posner, Economic Analysis of Law $\$ 4.9$ (2d ed. 1977).

13 Perlman, supra note 16, at 82 . 
should be restricted to instances either of interference by independently tortious means or of malicious interference, where malice can be demonstrated objectively by behavior likely to lead to a decrease in social wealth. ${ }^{28}$ Although it is true, as Perlman suggests, that the boundaries of interference liability are as yet unsettled, ${ }^{27}$ the paradigmatic case of intentional interference with a contract by lawful means has been actionable since Lumley $v$. Gye, ${ }^{28}$ even where the induced breach increases social wealth. The stability and uniformity of this core area of interference liability casts doubt on attempts such as Perlman's and Rizzo's to portray the essential concern of the tort as economic efficiency.

\section{B. Corrective Justice Criticism of Interference Torts}

Interference torts have also been questioned by corrective justice theorists. A common objection is that torts compensate for interference with property rights, something absent in interference torts. The most straightforward of recent criticisms in this vein is that of Professor Dobbs. ${ }^{29}$ Dobbs notes that malice alone cannot make an otherwise lawful act tortious. ${ }^{30}$ Following Prosser ${ }^{31}$ and Sayre, ${ }^{32}$ Dobbs concludes that "[i]f we protect [a] contract against all interference, we give it the quality of property-it becomes good against the world." ${ }^{33} \mathrm{He}$ attacks that attribution of the quality of property on the ground that it allows two parties between themselves to bind the conduct of strangers to their contract, ignoring the usual limitation of privity. ${ }^{34}$

Professor Perlman also criticizes the characterization of contract rights as property by analyzing the remedies allowed under actions for breach of contract and for interference with contract. ${ }^{35}$

${ }^{28}$ Id. at $94-97$.

${ }^{27}$ Id. at 64-67 (noting uncertainty as to the definition of the requisite mental state, types of contracts to be protected, and the means of interference that are actionable).

282 El. \& Bl. 216, 118 Eng. Rep. 749 (Q.B. 1853).

${ }^{29}$ See generally Dobbs, Tortious Interference with Contractual Relationships, 34 ARK. L. REv. 335 (1980).

so Id. at 347-48 (adjudication must turn on one's acts, not one's state of mind).

${ }^{31}$ W. Prosser, supra note 9, § 129, at 930-31.

s2 Sayre, supra note 1 , at 675 .

${ }^{33}$ Dobbs, supra note 29 , at 351 .

34 Id. at 350-56. Dobbs notes a number of exceptions to his objection to the imposition of constraints on third parties, including the creation of patents, which, he suggests, are the price society pays to encourage creativity. Id. In contrast, the formation of a contract, although it may result in an increase in the wealth of the parties, does not create new property. Id. at 352-53.

ss Perlman, supra note 16, at 91-93. 
Normally, the common law of contract does not compel performance, but gives an obligor the choice of performing or paying the obligee the value of his performance; ${ }^{36}$ barring the exceptional remedy of specific performance, the obligor's performance is not the obligee's property until the obligor has performed. The liability of an interferor to the obligee, on the other hand, includes the value of the contract and all foreseeable resultant harms ${ }^{37}$ and renders any contract between the obligor and the interferor that depends on the breach of the prior contract void for illegality. ${ }^{38}$ If an obligee is indifferent as to receiving performance or the value of performance, he is not harmed by interference with his contract, since he retains his right to the value of performance against the obligee; if contract damages are in fact undercompensatory, Perlman argues, "it seems a far better reform to adjust the damage rule in all breach cases rather than to attempt to reach full compensation only where there is a third-party inducer." 39

Professor Epstein's theory of corrective justice provides the most fundamental challenge to the notion that one who interferes with a contract infringes a property right in either of the contracting parties to performance. Epstein's analysis of tort law begins with an underlying theory that fixes the initial distribution of property rights ${ }^{40}$ by the rule of first possession: whoever first obtains physical control over a previously unowned thing acquires ownership..$^{41}$ Prior to first possession, no one, except perhaps the sovereign, can claim ownership. ${ }^{42}$ Having established first possession as the root of property rights, Epstein defines property rights, following tradition, ${ }^{43}$ as the right voluntarily to use, possess, and dispose of the thing owned. ${ }^{44} \mathrm{~A}$ tort is any act that coerces a property owner by force or fraud to relinquish a property right. ${ }^{45}$

36 Id. at 79-80 \& n.92.

${ }^{37}$ Interference with contract is a tort, hence an interferor is liable for all harms proximately caused by his tortious conduct. See $i d$. at 88 ; REstatement (SECOND) of TorTs $\S$ 774A (1979) (damages include consequential economic harms and emotional duress).

ss Restatement (Second) of Contracts § 194 (1981).

39 Perlman, supra note 16 , at 93 .

10 Epstein, Private Property and the Public Domain: The Case of Antitrust, in 24 NOMOS: THE LAW AND EcoNomics 48, 49 (1982).

11 See generally Epstein, Possession as the Root of Title, 13 GA. L. REv. 1221 (1979).

12 See, e.g., Pierson v. Post, 3 Cai. R. 175 (N.Y. Sup. Ct. 1805).

4s Epstein, supra note 40, at 77 n.20.

14 Id. at 57; Epstein, supra note 41, at 1221.

4s See Epstein, supra note 40, at 59 ("[i]n essence, therefore, force (taking or breaking) and misrepresentation are the only types of conduct that are constrained in B by a social recognition of ownership in A").

Because Epstein embraces strict liability, he cannot rely on the inherent limitations on 
Under Epstein's corrective justice analysis, interference liability suffers from two basic flaws. First, the obligee to a contract probably, and the potential beneficiary of an expectancy certainly, do not have ownership of the performance contracted for or expected, since neither has received that performance. Indeed, the whole purpose of contracts is to make certain that an obligee in fact receives the performance for which he bargained. Epstein gives as an example the case of Union Oil Co. $v$. Oppen. ${ }^{46}$ The plaintiffs in Oppen were fishermen whose livelihood was destroyed when the defendant spilled oil into the Santa Barbara Channel. The plaintiffs sued for the loss of the prospective value of the fish they would have caught, and the Ninth Circuit held the complaint stated a valid cause of action. ${ }^{47}$ Epstein finds this case an easy one:

The plaintiffs who do not own the fish cannot complain if the Union Oil Company captures them. As they cannot complain of capture, they cannot complain of destruction after capture. As they cannot complain of destruction after capture, they cannot complain of it before capture. No theory of tortious liability can make up the plaintiffs' deficit attributable to their want of ownership. ${ }^{48}$

Epstein's analysis is easily applied to interference torts. If the plaintiff has no ownership of the subject matter of the contract or expectancy, he has suffered no legally cognizable injury when that

liability imported into the prima facie case in a negligence system by foreseeability of harm. Epstein's theory compensates for the loss of proximate cause by strengthening the requirement of cause in fact. Causation must be more restrictive than "but for" causation in a theory of strict liability. Epstein narrows causation to four paradigms: $A$ hit or forced $B, A$ frightened $B, A$ compelled $B$ to hit $C$, and $A$ created a dangerous condition that was subsequently triggered, harming $B$. Epstein, $A$ Theory of Strict Liability, 2 J. LEgal Stud. 151, 166-89 (1973). Essentially, force or fraud are the only means of causation that fit within these paradigms.

t6 501 F.2d 558 (9th Cir. 1974).

47 Id. at 568-71.

48 Nuisance Law, supra note 18, at 52. The Oppen case illustrates the problem of an injury to a resource to which everyone has access but that no one owns. Either everyone is a proper plaintiff by virtue of his privilege of access, or no one is because no one owns the resource. Epstein's response to the common pool problem is government ownership of the common pool, at least in this case; exploitation would then be permitted only by license. Superfund, supra note 18 , at 35-36. Under the theory of this comment, liability would attach if the injurer of a common pool had notice of a plaintiff's pursuit of the pooled resource, see infra text accompanying notes $90-112$, hence the class of proper plaintiffs would be sharply limited. Thus, liability in Oppen would attach if the defendant had notice of the fishermen's activities. No question of privilege under the analysis set forth below arises, since the spilling of the oil was not a part of the pursuit of any commercial interest in the fish. 
contract or expectancy is interfered with.

Epstein's second objection derives from the implications of assigning property rights in expectancies. If such a property exists, then the beneficiary of the expectancy has some right to compel the future performance he seeks. This conclusion does not comport with the performer's right, as absolute owner of his labor, to dispose of it to whomever he wants. ${ }^{4 \theta}$ If the prospective performer is free to dispose of his labor, and he contracts with another party without coercion, then an action by the beneficiary of the prospective performance against that third party must fail on causal grounds: the voluntary act of the prospective performer in entering into a contract is a novus actus interveniens. ${ }^{.0}$

Epstein allows recovery for the value of an expectancy only in the case of interference with what he terms the "narrow" right to trade, which is the right to offer one's property to the world for exchange on whatever terms one wishes. ${ }^{51}$ The right to offer freely is part of the right to dispose that is an incident of ownership of one's property and person. ${ }^{52}$ When an interferor uses force or fraud to deprive someone of the opportunity to offer his property or services, the causal chain remains intact; the interferor has harmed the offeror's rights in his own property, not his interest in the property of a third party.

As a positive theory of economic torts, Epstein's analysis has several shortcomings. First, although he never explicitly discusses interference with formal contracts, his causal analysis there would seem to prove too much. If every voluntary, uncoerced act by the obligor to a contract were a novus actus, then the obligee would never have a cause of action against an interferor, such as the defendant in Lumley $v$. Gye, who merely makes the obligor a better offer. Second, Epstein's analysis does not account for the presence of malice as the central element in the courts' analysis of interference liability. Under Epstein's theory of strict liability, the tortfeasor's mental state forms no part of the prima facie case; mental states are relevant only in overcoming a defendant's otherwise valid affirmative defense. ${ }^{53}$ Third, Epstein leaves no room for

49 Intentional Harms, supra note 18, at 432.

so Id. at 431-33.

sI Id. at 428. For an example of such a case, see Tarleton v. M'Gawley, Peake 270, 170 Eng. Rep. 153 (K.B. 1793) (defendant fired shots at natives who were approaching the plaintiff intending to trade and scared them away).

s2 Intentional Harms, supra note 18, at 425-26.

ss Id. at 428-29. The prima facie case consists of the defendant's interference with the plaintiff's property right by one of the causal paradigms discussed supra note 45 . Id. 
liability for malicious interference with expectancies by otherwise lawful means, an area of liability recognized since Temperton. Fourth, Epstein does not explain the similar treatment the law accords the analysis of interference with both contracts and expectancies. ${ }^{54}$ Some other theory is needed to explain the law as it stands.

\section{Toward a Positive Theory of Interference Liability}

This comment builds from Epstein's strict liability theory of tort law. ${ }^{\mathrm{BS}}$ It differs from Epstein's account of property rights in that it recognizes rights in the free pursuit of economic advantages before the advantages are obtained. ${ }^{56}$ The remainder of this comment will concern itself with constructing and independently justifying, by appeal to cases concerning the capture of wild animals, the property rights whose infringement interference liability compensates. Those rights, as other commentators have pointed out, ${ }^{57}$ cannot be found in the performance expected or contracted for, since the existence of such rights would imply that a party negoti-

64 See W. Prosser, supra note $9, \S 130$, at 952.

${ }^{65}$ See generally supra notes $40-52$ and accompanying text.

BB An examination of Tarleton v. M'Gawley, Peake 270, 170 Eng. Rep. 153 (K.B. 1793) and variations of its facts will illustrate where Epstein's and this comment's accounts of interference torts, and their underlying property rights, diverge. The plaintiff in Tarleton was a shipowner whose ship was approaching the shore of Africa intending to trade with natives gathered there. The defendant's ship fired its guns at the natives, scaring them away. Epstein would hold the defendants liable, since they used force to interfere with the plaintiff's right to offer his goods to the natives. See Intentional Harms, supra note 18, at 429. Under the theory of this comment, liability would attach because the defendant, with notice, interfered with the plaintiff's expectancy in trade with the natives without having a direct commercial interest in that trade; i.e., the defendant did not deprive the plaintiff of his interest by making the natives a better offer.

In the first variation of the facts of Tarleton, assume that the defendant instead scares off the natives when he shoots at an albatross flying overhead, not knowing of the plaintiff's presence. Epstein would hold the defendant liable, since he used force to coerce the natives into not dealing with the plaintiff, thus interfering with the plaintiff's narrow right to trade. The theory advanced in this comment would find no liability, since the existence of a right to noninterference in the plaintiff against the defendant depends on the defendant's having had prior notice of the plaintiff's pursuit. See infra notes 90-112 and accompanying text.

In the second variation, assume the plaintiff and the natives had a prior contract. The defendant, knowing of the contract, arrives first, makes a better offer, and obtains the natives' wares. Epstein would find no liability, since the harm to the plaintiff's right to trade does not fit one of his causal paradigms, see supra note 45 , the harm is not caused by force or fraud, and the agreement by the natives with the defendant interrupts the causal chain. Under this comment's theory, the defendant would be liable, since the plaintiff would have a property right against the defendant in the pursuit of the contract not subject to a privilege for commercial interest. See infra notes 148-51 and accompanying text.

${ }^{87}$ See supra notes $29-39$ and accompanying text. 
ating a deal was in some sense already bound specifically to perform.

Prior analysis has incorrectly emphasized the relationship between the obligee and obligor, or prospective obligee and obligor. This comment will focus on the relationship between the obligee and the interferor as competing pursuers of the same economic good, the performance of the obligor. The relationship between pursuers of an economic good, viewed in isolation from the party whose goods or services they seek, is essentially indistinguishable from the relationship between pursuers of the same wild animal. By concentrating solely on the pursuers and their rights and privileges against each other, one avoids the questions of causation and indemnity that result from viewing those rights and privileges as channelled through the obligor or potential obligor. Both an obligee or potential obligee and a hunter seek an economic good that they as yet do not possess. Thus an analysis of cases concerning animals ferae naturae is doubly illuminating; not only are the wild animal cases the principal source of common-law jurisprudence concerning the acquisition of property rights, but they also provide an analogy to the interference cases, which concern the pursuit of some unpossessed good by competing individuals. ${ }^{58}$

Both the economic and corrective justice theorists discussed above intend their theories to be normative analyses, not positive accounts. Nonetheless, to the extent that a normative theory is not descriptive of existing case law, it must do more than provide an account of how those cases should have been decided; it must demonstrate by its own internal logic, and by its descriptive and explanatory power in other areas of the law, that it should be applied in areas where previously it has not been.

The raw "observations" of legal theories are cases, and unlike the observations underlying physical theories, they are always rational, for judges must give reasons for how they decide cases. Where the courts uniformly agree both as to certain paradigms of liability and as to the underlying structure of analysis and policy

ss Chief Judge Holt noted the similarity between the acquisition of property rights and interference torts in Keeble v. Hickeringill, 11 East 574, 103 Eng. Rep. 1127 (K.B. 1707), where he analogized the case at bar, in which the defendant frightened away the plaintiff's ducks, to a hypothetical case, in which one schoolmaster frightened students away from another. Keeble v. Hickeringill is reported several times and in different ways in the English reports. It is reported as Keeble v. Hickeringill, Cas. t. Holt 14, 17, 19, 90 Eng. Rep. 906, 907, 908, as Keble v. Hickeringill, 11 Mod. 74, 88 Eng. Rep. 898; 11 Mod. 131, 88 Eng. Rep. 945, and as Keeble v. Hickeringhall, 3 Salk. 9, 91 Eng. Rep. 659 (K.B. 1707). The comparison to the schoolmaster example is not found in all reports. 
justifying the imposition of that liability, it does not suffice for a normative theory simply to state that "there is no reason why the legal results should not be altered to conform to the theory." two rival normative theories, the one that preserves and justifies the existing case law, in both its holdings and its reasoning, with greater fidelity is to be preferred, all else being equal.

The theory advanced in this comment is part positive, part normative. It is positive in that it relies solely on principles derived from legal sources in characterizing the structure of liability it presents. It is normative in that it argues that liability for interference with economic relations should be imposed according to a structure of rules derived by extending general legal principles to economic harms, where they have been rarely applied.

This comment will argue that the right to free pursuit of unacquired property, including unacquired performance, is a right recognized not only by cases imposing liability for interference with contracts and expectancies, but by the general common law concerning the acquisition of property. Once that right has been demonstrated, an analysis of its extent will account for several features of interference liability, including damages exceeding the value of the underlying performance, the role of the mental element commonly deemed "malice" in the prima facie case, the function of privilege in liability for interference with expectancies, and the similar treatment accorded interference with both contracts and expectancies. The analysis will then be applied to well-known interference cases, where it will provide a positive corrective justice account for the core areas of liability. ${ }^{60}$

\section{Property Rights IN Pursuit}

A. The Existence of Rights in the Pursuit of Wild Animals

An analysis of the common law of acquisition of property should begin with the famous case of Pierson $v$. Post. ${ }^{61}$ Plaintiff Post was chasing a fox in plain view of defendant Pierson on an unpossessed stretch of beach. Pierson rushed in, killed the fox, and carried it off. ${ }^{62}$ The question before the court was whether Post, "by the pursuit with his hounds in the manner alleged in his declaration, acquired such a right to, or property in, the fox as will sus-

\footnotetext{
59 Intentional Harms, supra note 18, at 431.

so See supra notes 9-14 and accompanying text for an account of those areas.

61 3 Cai. R. 175 (N.Y. Sup. Ct. 1805).

${ }^{62}$ Id. at 175 .
} 
tain an action against Pierson for killing and taking him away." After surveying the history of, and commentary on, the taking of wild animals since Justinian, the court held that no right in a pursued animal accrues until its "pursuer manifests an unequivocal intention of appropriating the animal to his individual use, has deprived him of his natural liberty, and brought him within his certain control," either by manucaption, securing the animal with nets, or mortal wounding. ${ }^{64}$ Since the fox was not within Post's certain control, the court held that Pierson had caused him no cognizable injury.

Another case commonly cited for the proposition that a pursuer of a wild animal acquires no rights until capture is Young $v$. Hichens. ${ }^{68}$ In that case, the plaintiff had drawn his nets around a school of fish, leaving a gap of some seven fathoms, in which two of the plaintiff's boats were stationed, splashing water so as to frighten the fish away from the opening. The defendant rowed through the opening and seized some of the fish, allowing the rest to escape and tearing the plaintiff's nets in the process. ${ }^{68}$ The plaintiff sued for damage to his nets and for conversion of the fish. ${ }^{67}$ Argument before the Queen's Bench turned on whether the plaintiff, by nearly closing his nets and stationing men in the gap, had obtained sufficient physical control over the fish to vest title in him. In what is regarded as the crux of the case ${ }^{68}$ Lord Denman concluded:

It does appear almost certain that the plaintiff would have had possession of the fish but for the act of the defendant: but it is quite certain that he had not possession. Whatever interpretation may be put on such terms as "custody" and "possession," the question will be whether any custody or possession has been obtained here. I think it is impossible to say that it had, until the party had actual power over the fish. ${ }^{68}$

Lord Denman then noted, in a rarely discussed passage, that "[i]t may be that the defendant acted unjustifiably in preventing the plaintiff from obtaining such power: but that would only show a wrongful act, for which he might be liable in a proper form of ac-

c3 Id. at 176 .

ot Id. at 178 .

65 Q.B. 606, 115 Eng. Rep. 228 (1844).

as Id. at 607-08, 115 Eng. Rep. at 228.

${ }^{67}$ Id. at 606-07, 115 Eng. Rep. at 228.

ss See, e.g., O.W. Holmes, The Common Law 217 (1881).

-6 6 Q.B. at 611, 115 Eng. Rep. at 230. 
tion."70 Thus Lord Denman suggests that the plaintiff may have failed to recover because he sued under the wrong writ, not because he was without a legally protected right.

The right in pursuit recognized in Lord Denman's dictum is vindicated in Keeble $v$. Hickeringill. ${ }^{71}$ The plaintiff in Keeble sued in an action on the case for the defendant's having "deprive[d] him of the use and benefit of [a] decoy pond"72 used to attract ducks in order to capture them. The defendant, standing on his own land adjacent to plaintiff's, fired guns on two occasions to scare away the ducks. ${ }^{73}$ The defendant moved that the declaration was not good since the plaintiff did not own the ducks. Chief Judge Holt rejected this defense, "for this action is not brought for his property, but is brought for hindering him to take his profit."" "[I]f Mr. Hickeringill had set up another decoy on his own ground near the plaintiff's, and that had spoiled the custom of the plaintiff, no action would lie, because he had as much liberty to make and use a decoy as the plaintiff." "In the case at bar, the defendant acted not in the exercise of his own liberty to make a decoy; his acts were "malicious." Since the action was brought for harm not to the plaintiff's property in the ducks, but for hinderance of his profit, it was enough that the ducks were "in the plaintiff"s decoy pond, and so in his possession, which is sufficient without showing that he had any property in them."77 To restate Chief Judge Holt's conclusion, the plaintiff in Keeble had a right in the profit from the duck pond good against the world, subject to a privilege in anyone exercising the same right to pursue ducks; ${ }^{78}$ that is, the plaintiff may prevail against any interferor with his decoy pond except one pursuing the same ducks by means not otherwise tortious. ${ }^{79}$ Among

${ }^{70}$ Id. The right form of action would probably have been an action in trespass on the case or trover. Broadly speaking, trespass on the case was the immediate common-law antecedent for the modern negligence action, and trover was the most common action for trying title to moveable goods. See F. Maitland, The Forms of Action at Common Law 71 (1948).

713 Salk. 9, 91 Eng. Rep. 659 (K.B. 1707). See supra note 58.

${ }^{72}$ Id. at 9, 91 Eng. Rep. at 659 (emphasis omitted).

73 Id.

74 Cas. t. Holt at 19, 90 Eng. Rep. at 909.

7511 East at 576, 103 Eng. Rep. at 1128.

${ }^{76} 3$ Salk. at 9, 91 Eng. Rep. at 659.

773 Salk. at 10, 91 Eng. Rep. at 659 (emphasis in original).

78 See generally Hohfeld, Some Fundamental Legal Conceptions as Applied in Judicial Reasoning, 23 YALE L.J. 16 (1913) (particularly the discussion of privilege at 34-35).

${ }_{79}$ This pattern of rights in property with reciprocal privileges in other users is not unique to wild animal or interference law. It occurs again in the pattern of rights to a stream vested in an owner of riparian land. Under the so-called American rule, a riparian owner, by virtue of his owning land bordering a stream, has a right to use as much water as 
themselves, no pursuer acquires rights superior to those of any other pursuer. The defendant in Keeble was not a pursuer and hence not within the scope of this privilege.

Both Pierson and Young recognize that although a pursuer may not have sufficient control over an animal to create rights in the animal itself, he may still have rights in the free pursuit of that animal. Keeble adds that the right of a pursuer to free pursuit, before he obtains any control over the animal, is good against all but other pursuers. ${ }^{80}$

Two cases from the whaling industry illustrate the next stage in the process from pursuit to capture. In this stage, the initial pursuer has gained some degree of physical control over the animal pursued, though not enough to satisfy the complete control requirement of the first possession rule. Because the pursuer has gained some control, he stands on superior footing to pursuers who have not, as well as to nonpursuers. The pursuer in this stage has gained control by "first possession" of the right to pursue. ${ }^{81}$

he can put to beneficial use, 6A American Law of Property $\$ 28.56$, at 163-64 (A. Casner ed. 1954), subject to the absolute privilege of a prior (i.e., upstream) user to appropriate water for natural use or use directly related to his ownership of riparian land. Id. at 165. A similar pattern occurs in rights to a common pasture.

- It is possible that Pierson also recognizes that rights in pursuit may vest prior to capture. The court took great pains to distinguish Pierson from Keeble. The court's discussion of Keeble is contained in one paragraph:

The case cited from 11 Mod. 74-130, I think clearly distinguishable from the present; inasmuch as there the action was for maliciously hindering and disturbing the plaintiff in the exercise and enjoyment of a private franchise; and in the report of the same case, (3 Salk. 9,) Holt, Ch. J., states, that the ducks were in the plaintiff's decoy pond, and so in his possession, from which it is obvious the court laid much stress in their opinion upon the plaintiff's possession of the ducks, ratione soli.

3 Cai. R. at 178-79. Lest the word "possession" be misunderstood, Holt states that the plaintiff had a cause of action by showing merely that the ducks were "in the plaintiff's decoy pond, and so in his possession, which is sufficient without shewing that he had any property in them." 3 Salk. at 10, 91 Eng. Rep. at 659 (emphasis in original). Thus the court in Pierson could not have been distinguishing Keeble on the grounds that the plaintiff in Keeble already owned the ducks. It is reasonable to infer, therefore, that Pierson's reference to plaintiff's "private franchise" was in recognition of a right to use a decoy to attract ducks, which suggests a right not to be interfered with maliciously in the pursuit of ducks on one's own land.

1 An analogy may be found in the common-law mining doctrine of pedis possessio. A prospector on public lands does not acquire title to minerals until he has actually discovered them and filed a patent. See 30 U.S.C. $\$ \S 23,29,37$ (1976). Prior to discovery, however, if a miner maintains continuous actual occupancy of a claim, works his claim diligently, and denies entry to rivals, he is protected against competing claims made by others after forcible, fraudulent, clandestine, or surreptitious entry. See Union Oil Co. v. Smith, 249 U.S. 337, 346-48 (1919). See generally Comment, The General Mining Law and the Doctrine of Pedis Possessio: The Case for Congressional Action, 49 U. CHI. L. Rev. 1026 (1982). 
In Littledale v. Scaith, ${ }^{82}$ the.plaintiff owned a whaling ship whose harpooner struck a whale; the harpoon remained in the whale, and the harpooner retained control of the line. The defendant then harpooned the whale and killed it. The plaintiff sued in trover $^{83}$ for the whale. The facts in Hogarth v. Jackson ${ }^{84}$ are identical save in two respects: the harpoon had not remained in the body of the whale, although the whale apparently remained entangled in the plaintiff's line, and the plaintiff sued both in trover and for "having interrupted the plaintiffs in killing a whale." cases were adjudged for the plaintiffs. In the words of the latter court:

"[I]f the harpoon or line breaks, or the line attached to the harpoon is not in the power of the striker, the fish is a loose fish, and will become the property of any other person who strikes and obtains it."

... [I]f the fish is attached by means, such as the entanglement of the line, or other cause, to the boat of the party first striking it, so that such party may be said to have the power over it, it is considered as a fast fish, and cannot be taken by any other vessel. ${ }^{86}$

As the complaint in Hogarth suggests, the right interfered with is not the right of ownership in the whale, but the right to exclusive pursuit without interference. ${ }^{87}$ One line in a whale could not by itself guarantee the certain control required by Pierson $v$. Post for the vesting of title in the first harpooner. ${ }^{88}$ The line fast in the whale and firm in the hand of the harpooner represents the directness of connection that ensures the right to free pursuit. ${ }^{89}$

821 Taunt. 243a, 127 Eng. Rep. 826 (York Assizes 1788).

${ }^{83}$ Regarding trover, see supra note 70.

842 Car. \& P. 595, 172 Eng. Rep. 271 (C.P. 1827).

ss Id. at 595, 172 Eng. Rep. at 271.

${ }^{88} I d$. at 596, 172 Eng. Rep. at 271 (quoting Fennings v. Lord Grenville, 1 Taunt. 241, 127 Eng. Rep. 825 (C.P. 1808)).

87 An action in trover was generally brought for the value of goods wrongfully converted. F. MaITLAND, supra note 70, at 71. Since it was an offshoot of trespass, damages were commonly limited to money. The essence of the action is the plaintiff's immediate right to possession; unlike the writ of trespass proper, the plaintiff need not prove that he had actual possession. $7 \mathrm{~W}$. Holdsworth, A History of English Law 421 (1926).

${ }^{88}$ See generally H. Melville, The Whale; or Moby Dick (London 1851).

${ }^{82}$ But cf. Fennings. v. Lord Grenville, 1 Taunt. 241, 127 Eng. Rep. 825 (C.P. 1808), a whaling case somewhat contrary in spirit to the two principal cases. While noting that the rule in Littledale was accepted as the custom of the Greenland whale fishery, the court found that the custom of the "Gallipagos [sic] Islands fishery" was to allow the party who first struck a whale to share it equally with the eventual killer. Id. at 242-43, 127 Eng. Rep. 
Lacking that connection, a pursuer, such as the plaintiff in Pierson, cannot complain of interference by another pursuer.

\section{B. Mental States}

In many of the cases concerning rights in the pursuit of wild animals, an analysis of the mental states of both the interferor and the pursuer plays a prominent role. Holt, for example, grounds the defendant's liability in Keeble on his malice in scaring the plaintiff's ducks. ${ }^{90}$ The court in Pierson, on the other hand, finds that the pursuer of a wild animal may not maintain an action against an interloper for taking the animal unless he has at least mortally wounded the animal, for it is only then that the pursuer "manifests an unequivocal intention of appropriating the animal to his individual use."

The importance of mental state in the prima facie case of interference liability has troubled many observers, ${ }^{92}$ for "[i]t is certainly a general rule of our law that an act prima facie lawful is not unlawful and actionable on account of the motive which dictated it."93 The first of the supposed mental elements figuring in the wild animal cases, the motive of the interferor, is not part of the prima facie case, nor is it in fact a mental state at all. It is instead an affirmative defense of privilege. Pursuers of a wild animal, at least until one of them wounds or confines the animal, have reciprocal privileges of pursuit by virtue of their status as pursuers, which is the same status that is the source of their right to noninterference by nonpursuers.

The presence or absence of the privilege of pursuit in the interferor does not alone determine liability, however. Pursuers who

at 826 . The case reports, however, that the rule was not universally followed. Id. at 242,127 Eng. Rep. at 826. In any event, the holding in Fennings does not bear directly on the result in the two principal cases where the plaintiffs held fast lines. Cf. Swift v. Gifford, 23 F. Cas. 558,560 (D. Mass. 1872) (No. 13,696) (noting that the American custom of awarding a whale to the first striker, provided he lays claim to the whale before a second boat kills and cuts into it, overcomes the general rule of first possession).

30 Salk. at 9, 91 Eng. Rep. at 659. See also Carrington v. Taylor, 11 East 571, 572-73, 103 Eng. Rep. 1126, 1127, 2 Camp. 258, 170 Eng. Rep. 1148 (K.B. 1809) (the court predicates liability for interference with the plaintiff's duck decoy on the defendant's "wilful disturbance").

213 Cai. R. at 178.

92 See, e.g., W. Prosser, supra note $9, \S 129$, at 927 (noting that "a wrongful motive in itself may turn the scale in favor of liability," but questioning rationale); Intentional Harms, supra note 18, at 394 ("the defendant's intention to harm . . . [is] insufficient to state a prima facie case").

${ }^{\circ 3}$ Allen v. Flood, 1898 A.C. 1, 123-24 (H.L. 1897) (Lord Herschell). 
have acquired a certain degree of physical control over the animal pursued, such as the plaintiff in Hogarth, may maintain an action for interference against other pursuers, regardless of privilege. A second true mental element forms part of the prima facie case of all pursuit cases; the interferor is not liable unless he had notice of the pursuit by the first pursuer.

This requirement of notice finds its source in the traditional analysis of possession as comprising an element of power and an element of intent. ${ }^{94}$ A typical statement of that analysis may be found in Pierson: a pursuer of a wild animal "obtains possession," and hence owns it, when he "manifests an unequivocal intention of appropriating the animal to his individual use, has deprived him of his natural liberty, and brought him within his certain control." For the understanding of interference torts, the essential word in that statement is "manifests," for it is only by making his intention to pursue known to others that the pursuer gains any right to free pursuit.

The intent required to vest a property right is an objective one. Oliver Wendell Holmes's discussion of possession in The Common Law reflects the objective quality of the intent required for perfection of property rights. Holmes analyzed the requisite intent in terms of the duties the law imposes on nonowners in dealing with owners and their possessions. Duties are antecedent to rights. The direct action of the law is a limitation on the freedom of action of certain individuals, and rights are the vesting in other individuals of the capacity to enforce that limitation. ${ }^{96}$ The duty the law imposes is the obligation not to interfere with another's property, and the right vested by ownership is essentially the right not to be interfered with or the right to exclude others from the use and enjoyment of one's property. ${ }^{97}$ The intent the law requires as a predicate to the right of ownership, then, is not the intent to "appropriate" a thing for one's own use, as Judge Tompkins deems it in Pierson," but rather the "intent to exclude others." to create a duty in another not to interfere with the owner's use or enjoyment of his property, the owner must intend to exclude that

or It is almost a tautology that the existence of property rights in things physical or incorporeal requires proprietary intent; if $A$ does not intend to claim ownership of a thing, even if it is within his power, then $B$ may simply appropriate it for his own use.

os 3 Cai. R. at 178.

os O.W. HoLmes, supra note 68 , at 219-20.

97 Id. at 220.

${ }^{98} 3$ Cai. R. at 178 .

o.W. Holmes, supra note 68, at 220. 
individual from his property.

Property rights do not rest upon purely subjective intent; proprietary intent cannot remain locked in the owner's breast. ${ }^{100}$ Even where physical control has been exercised over a thing, the mere desire to exclude others will not suffice to maintain a right against the world unless that desire has been made known to the person excluded. ${ }^{101}$ For example, a bona fide purchaser from a person with apparent power to convey will prevail in cases where the original owner is a bailor, ${ }^{102}$ and he may prevail if he records his deed before a prior purchaser. ${ }^{103}$ The law creates no duty in the subsequent taker until he has notice of the prior owner's title; as against the subsequent taker the owner has no rights until he has given him notice, actual or constructive.

One area in particular in which the law protects a taker of property without notice is intellectual property. At least two commentators have analogized the law of intellectual property to interference law, ${ }^{104}$ principally because the objects of interference torts, contract and expectancies, like patents, copyrights, and trade secrets, are incorporeal. Although physical objects give notice in most cases of the existence of some owner, ideas and contractual relations do not. Actual or constructive notice must be given before rights in ideas and contracts can be perfected. ${ }^{100}$

Professor Epstein's remarks on intellectual property are revealing:

Patents and copyrights, for example, create property rights in their owners that cannot be reduced to physical possession.

${ }^{100}$ This is also true elsewhere in the law. For example, the law of inchoate crimes requires some overt act or substantial step as evidence of fixity of intent before it will impose liability for conspiracy or attempt. See W. LaFave \& A. ScotT, Handbook on Criminal Law $\S 59$, at $431-32, \S 62$, at 476 (1972).

101 The requirement of manifest notice of the intent to exclude explains the exceptional treatment the law accords lost wild animals. Normally, a lost chattel remains the property of its owner until he abandons it. Clark v. Maloney, 3 Del. (3 Harr.) 68 (Del. Sup. Ct. 1840). Possession of a wild animal, however, is lost as soon as an animal escapes, Reese v. Hughes, 144 Miss. 304, 305, 109 So. 731, 732 (1926); Mullet v. Bradley, 24 Misc. 695, 696, 53 N.Y.S. 781, 782 (N.Y. Sup. Ct. 1898), unless the animal is identified by earmarking, see, e.g., E.A. Stephens \& Co. v. Albers, 81 Colo. 488, 256 P. 15 (1927), or has become so domesticated as to have an animus revertendi, W. BLACKSTONE, CommentaRIES *392. Whereas an inanimate object may be presumed to be owned by someone who, without further evidence, has probably not abandoned it, a wild animal, absent the circumstances noted above, does not give similar notice of its possession.

${ }^{102}$ See, e.g., Zendman v. Harry Winston, Inc., 305 N.Y. 180, 111 N.E.2d 871 (1953).

${ }^{103}$ See, e.g., Patterson v. Bryant, 216 N.C. 550, 5 S.E.2d 849 (1939).

104 See Dobbs, supra note 29, at 352-53; Intentional Harms, supra note 18, at 425.

${ }^{103}$ See infra note 107 and accompanying text. 
Yet once their subject matter is identified, they share the essential features of tangible property in that they too create rights of exclusive use and control good against the entire world. These interests, moreover, are protected by actions against infringement that are strict in form, as the defendant's intention to appropriate plaintiff's copyright or patent for his own use forms no part of the prima facie case. ${ }^{108}$

While stressing that actions for patent or copyright infringement, like those protecting other species of property, are strict in form, Epstein's account glosses over the statutory requirement of registration and appropriate labeling, without which an action for infringement cannot be maintained. ${ }^{107}$ The function of such requirements is to provide the world with constructive notice of the owner's intent to exclude others from the unlicensed use of his idea. ${ }^{108}$ The one common-law intellectual property right, protection of trade secrets, has much the same contours as the law of bailments: anyone who learns of a trade secret, and has reason to know that it is a trade secret and that the person from whom he learned it breached a duty to its owner by disclosing it, is liable to its owner for use or disclosure; ${ }^{109}$ one who acquires a trade secret without notice, however, may disclose it without liability and, in so doing, destroys the original owner's rights in it as against subsequent users. ${ }^{110}$

${ }^{108}$ Intentional Harms, supra note 18, at 425 (footnote omitted).

${ }_{107} 17$ U.S.C. $\S \S 401,411,412$ (1976) (copyrights); 35 U.S.C. $\S \S 111,287$ (1976) (patents).

${ }^{108}$ Because of the lack of opportunity for recording the pursuit of wild animals, most actions for interference with that pursuit rest on actual knowledge. Notice of pursuit, however, like notice of other species of incorporeal property, may be actual or constructive, hence a plaintiff need not show that the defendant knowingly interfered with his pursuit, merely that he should have known. Carrington v. Taylor, 11 East 571, 103 Eng. Rep. 1126, 2 Camp. 258, 170 Eng. Rep. 1148 (K.B. 1809), illustrates the distinction. The plaintiff owned an "ancient decoy" of "long uninterrupted enjoyment" in which he was accustomed to capturing wildfowl. 2 Camp. at 258, 260, 170 Eng. Rep. at 1148, 1149. The defendant in turn was licensed to shoot wildfowl on the river where the decoy was situated. 11 East at 572, 103 Eng. Rep. at 1126. The plaintiff brought an action for the disturbance caused to his decoy by the defendant's firing his gun. There was no evidence that the defendant knew of the decoy, since he did not approach nearer to it than two or three hundred yards, nor did the defendant fire at the ducks in the decoy, 2 Camp. at 258, 170 Eng. Rep. at 1148; indeed, the defendant argued that, since the interference was "innocent, the foundation of the action failed." Id. at 259, 170 Eng. Rep. at 1148. The court upheld the action, finding the defendant's interference malicious as a matter of law where the decoy is ancient. Id. at 259-60, 170 Eng. Rep. at 1148-49.

109 Restatement of Torts $§ 757$ (1939). See, e.g., Space Aero Prods. Co. v. R.W. Darling Co., 238 Md. 93, 113-15, 208 A.2d 74, $84-85$ (1964), cert. denied, 382 U.S. 843 (1965). ${ }^{110}$ Underwriter Storage, Inc. v. United States Rubber Co., 371 F.2d 950, 954-55 (D.C. 
Liability for interference with the pursuit of wild animals, suggests Holt, ${ }^{111}$ is predicated on malice. If malice is taken to mean intent to inflict harm, it is difficult to see how malice can be an element of the prima facie case of either a strict liability or a negligence tort. Broken down into notice and lack of privilege, however, malice's role in interference torts emerges. Without notice of the pursuit, an interferor has no duty not to interfere, and hence the pursuer has no right in the pursuit enforceable against him; Keeble would not have had an action against Hickeringill if Hickeringill had only discharged his guns while hunting on his own land or in self-defense, oblivious to Keeble's decoy. Privilege negates malice and serves as an affirmative defense, protecting fellow pursuers of the same animal where no pursuer has yet exerted a significant degree of control over the object of pursuit. ${ }^{112}$

In the first stage of pursuit, before any such control is achieved, liability attaches only where the interferor has notice of the pursuit and is not himself pursuing the same object. Notice plus lack of interest in the pursuit imply malice in the traditional sense. The law of interference torts presumes the intent to bring about the natural and probable results of interference from the interferor's knowledge of competing pursuers, and his lack of interest in the pursuit suggests an intent solely to harm the pursuer. In the second stage of pursuit, the interferor's liability is predicated on notice alone, without regard to whether he is pursuing the animal. The plaintiffs in Littledale and Hogarth did not need to plead or prove malice to recover for interference once their whales were fast.

\section{Interference Liability and Stages of Acquisition of Property Rights in Pursuit}

From the preceding examination of the acquisition of rights in wild animals four stages may be discerned. This four-stage structure of liability is comparable to the structure of interference liability. First, of course, is the stage before pursuit commences. In this stage, no cause of action exists even for the most direct and

\footnotetext{
Cir. 1966), cert. denied, 382 U.S. 911 (1967).

${ }^{111}$ Keeble, 3 Salk. at 10, 91 Eng. Rep. at 659 ("an action will lie . . . for a malicious act done by one to another").

112 See Keeble, 11 East at 576, 103 Eng. Rep. at 1128 ("[I]f Mr. Hickeringill had set up another decoy on his own ground near the plaintiff's, and that had spoiled the custom of the plaintiff, no action would lie, because he had as much liberty to make and use a decoy as the plaintiff.").
} 
malign interference; Post could not have complained if, while he sat sunning himself on the beach, Pierson slew the fox out of spite. $^{113}$ The last stage equally clearly is that of ownership by virtue of first possession. The rights of ownership correspond to those that attach to an executed contract for purposes of interference law. Pierson seems to stand for the proposition that no intermediate stages exist. ${ }^{114}$

The foregoing analysis, however, suggests the existence of two intermediate stages. The first, demonstrated in Keeble, is reached when the pursuer begins the pursuit of a specific animal or group of animals. Liability at this stage rests on notice of the pursuit plus lack of the privilege conferred by the interloper's pursuit. As noted above, in most circumstances these two elements imply malice, on which liability for interference with expectancies is traditionally said to rest, ${ }^{110}$ and they find their analogues in interference law in notice of the expectancy on the part of the interferor and a lack of genuine commercial interest in the object of the expectancy. Notice of the expectancy is required if the party interfered with is to have a right good against the interferor, because notice is necessary to evidence the intent to exclude that is a predicate of ownership. The second element, lack of a genuine commercial intent, negates the interferor's right to pursue which, at this stage, would otherwise stand on equal footing with the rights of the party interfered with, giving him a privilege to interfere. ${ }^{116}$

The second intermediate stage of the pursuit of a wild animal, demonstrated in Hogarth, succeeds the first when the pursuer has exerted a significant degree of control over the animal by wounding it, putting a line in or around it (as in Hogarth), or surrounding it. At this stage, the pursuer has obtained an exclusive right to pursue that animal. The pursuer may maintain an action for interference

113 An example of such a case in the realm of economic harms is provided by Mayor of Bradford v. Pickles, 1895 A.C. 587 (H.L.). The plaintiff represented the Borough of Bradford, which lay below land owned by the defendant. The defendant dug a shaft into his land, the effect of which was to diminish the flow from, and discolor two springs on, the plaintiff's land fed by water percolating down from the defendant's land. The plaintiff alleged that the defendant maliciously interfered with the flow of water in order to force the Borough to buy him out. Id. at 589 . The court held that where the plaintiff has no property rights whatever in the percolating water, the defendant's motives, however malicious, were irrelevant. Id. at 594, 598-99, 601 .

114 See, e.g., supra text accompanying notes 61-64.

115 W. Prosser, supra note $9, \S 130$, at 952.

${ }_{110}$ See supra note 79 , where it is observed that a riparian owner has a privilege to appropriate for natural uses, where no such privilege exists for non-natural uses. A similar structure of rights exists here, where a privilege exists only for commercial appropriation of expectancies. 
against anyone with notice of the pursuit, regardless of the motive of the interferor. By wounding or trapping the animal, the pursuer obtains rights superior to those of any new pursuer in the pursuit. This stage in the pursuit of animals corresponds to that of an executory contract in the area of economic torts; although the contract does not convey a property right in the performance of the obligor, it does confer on the obligee an exclusive right to pursue that performance free from interference.

This analysis of economic torts as interferences with rights in pursuit of performance solves the two problems of damages that concerned Professor Perlman. Perlman noted that the damages recoverable for interference with contracts and expectancies exceed either the amount recoverable from the obligor or prospective performer (in the latter case, zero) or the value of the performance. $\mathrm{He}$ also noted that in the case of contracts, the obligee remains entitled to contract damages against the obligor, which are in theory equal to the value of performance, hence the obligee seems to have suffered no harm. ${ }^{17}$ Under the present theory, the amount of damages recoverable for interference torts represents the proximate consequences of interference with the right to pursue, only one of which is the loss of the value of performance, and which include emotional harm and loss of good will.18

For both stages of liability, the theory of this comment requires that the two central notions of interference liability, notice and privilege of pursuit (in the case of wild animals) or of commercial interest (in the case of contracts and expectancies), be read narrowly. When $A$ engages in pursuit and gives $B$ notice of the pursuit, $A$ 's rights and privileges against $B$ extend only to the object of his pursuit. In the first stage of pursuit the source of $A$ 's privilege to interfere with $B$ 's pursuit is the symmetry of their positions with respect to the animal or good pursued. When $A$ and $B$ pursue different objects, each has a right to pursue that is good against the other, but neither has a privilege to interfere. For example, if the defendant in Oppen ${ }^{119}$ had notice that the fishermen

${ }_{117}$ See supra notes 35-39 and accompanying text.

$11 \mathrm{Cf}$. the remarks of Judge Compton in Lumley:

Nor is it an answer, to say that there is a remedy against the contractor, and that the party relies on the contract; for . . . the action on the contract and the action against the malicious wrong-doer may be for a different matter; and the damages occasioned by such malicious injury might be calculated on a very different principle from the amount of the debt which might be the only sum recoverable on the contract.

2 El. \& Bl. at 229-30, 118 Eng. Rep at 754.

130 See supra notes 46-50 and accompanying text. 
regularly fished the Santa Barbara Channel, the fact that oil spills were a consequence of the defendant's search for oil would not confer on it a privilege to harm the fishermen's expectancy in the fish.

Temperton v. Russell ${ }^{120}$ demonstrates the operation of notice and the privilege of commercial interest. The plaintiff in Temperton was a master mason who supplied materials to a building firm; he had refused to break contracts with those builders who would not obey union rules. Defendants, members of a joint committee of three trade unions, persuaded suppliers of the plaintiff to breach existing contracts and not to enter into further contracts with him. Even though the defendants acted to advance their own commercial interests, the court found they had no interest in the subject matter of the plaintiff's contracts and expectancies, hence under the theory of this comment, liability was rightly imposed.

The Restatement (Second) of Torts recognizes a privilege that is broader in two respects. First, it recognizes a privilege for a knowing interference with a contract if the interference is sufficiently remote and is done to further an independent, primary interest of the interferor, such as his own commercial interests. ${ }^{121}$ Second, it protects an interferor with an expectancy who acts to safeguard his preexisting financial interest in the goods or services pursued by another. ${ }^{122}$ The basic privilege, however, extends only to competition for the same goods or services. ${ }^{123}$

The quality of notice implicit in the intent requirement varies according to the type of property involved. Generally speaking, notice is of three types: actual, constructive, and inquiry. Constructive notice is notice imputed by law from certain facts, chiefly from recording. Inquiry notice is provided by information which would cause a reasonable person to engage in an inquiry that would disclose the facts in question. ${ }^{124}$ It is generally impractical for a pursuer of wild animals to give other than actual notice, since he typically will be in hot pursuit. ${ }^{125}$ Rights of ownership in trade secrets, on the other hand, may be maintained against anyone who has reason to suspect that he has learned of what might be a trade secret

120 [1893] 1 Q.B. 715. (1979).

${ }^{221}$ Restatement (Second) of Torts $\S \S 766$ comment j, 767 comment d, 768(1)(d)

${ }^{222} I d$. § 769.

12s Id. \& 768 comment d.

124 See generally O. Browder, R. Cunningham, J. Julin \& A. Smith, Basic Property LAW 899-904 (3d ed. 1979).

${ }^{125}$ But see the discussion of Carrington v. Taylor, supra note 108. 
through possibly improper means. ${ }^{126}$ As to contracts and expectancies, constructive notice, with the exception of contracts for the sale of land in some jurisdictions, ${ }^{127}$ is not available, and courts seem unwilling to allow recovery based on inquiry notice unless that notice is of facts relating to specific contracts or expectancies and not to a general course of trade. Thus in Tarleton $v$. $M^{\prime}$ Gawley, ${ }^{128}$ the court found the defendant liable for firing at, and scaring away, natives who had gathered at the shore intending to trade with the plaintiff's ship, which was laying off the coast; in contrast, the court in Byrd v. English ${ }^{\mathbf{1 2 9}}$ declined to impose liability on a defendant whose workmen negligently damaged electric lines leading to the plaintiff's neighboring plant. This restriction of inquiry notice to facts concerning a specific contract or expectancy parallels the restriction of the privilege of pursuit to pursuit of the same economic advantage discussed above. ${ }^{130}$

\section{INTERFERENCE TORTS}

This comment has provided a theoretical basis for interference torts. It has shown that, like other torts, interference torts protect recognized property rights, in particular, a right in pursuit. The mental element of malice traditionally associated with interference liability is described in this theory as composed of the notice required to exclude others, which is an element of the prima facie case, and the lack of an affirmative defense of privilege. This part treats a number of well-known interference cases in light of the property analysis derived from wild animal cases discussed above.

\section{A. Expectancies}

Gregory v. Duke of Brunswick ${ }^{\mathbf{1 3 1}}$ provides a clear case of liability for interference with an expectancy. Gregory had entered into an at-will contract to perform Hamlet. On opening night, the two defendants and a substantial portion of the audience hooted and jeered the plaintiff off the stage because of their hostility to a newspaper published by the plaintiff. The management rang down the curtain. Plaintiff was discharged and sued the defendants for the remaining value of the contractual series of performances as

\footnotetext{
126 See Restatement of ToRTs $\S 757$ comment $l$, illustrations $3 \& 4$ (1939).

127 See, e.g., Ohio Rev. Code. ANN. § 5301.25 (Page 1981).

128 Peake 270, 170 Eng. Rep. 153 (K.B. 1793).

120117 Ga. 191, 43 S.E. 419 (1903).

130 See supra notes $111-12$ and accompanying text.

1316 Man. \& G. 205, 953, 134 Eng. Rep. 866, 1178 (C.P. 1843).
} 
well as the harm occasioned by his subsequent inability to find employment as an actor. Although the jury later found that the plaintiff's harms could not be traced to the defendants' actions, and hence awarded the plaintiff no damages, ${ }^{132}$ the court found, in overruling the defendant's demurrer, that a conspiracy to prevent the plaintiff from performing so as to hinder him in advancing his career stated a cause of action. ${ }^{133}$ Given the foregoing analysis, liability properly followed from knowledge plus lack of commercial interest in the expectancy, even though hissing in a theater is perfectly legal. ${ }^{134}$

Where either notice of the expectancy is lacking or a commercial interest in the expectancy exists, an interferor with an expectancy will not incur liability. Tuttle v. Buck ${ }^{135}$ and Allen $v$. Flood ${ }^{136}$ illustrate the consequences of a legitimate commercial interest where the defendant has knowingly interfered with an expectancy. In the latter case, defendant Allen was a representative of the boilermakers' union; the plaintiffs were rival shipwrights. The boilermakers' union objected to the employment of shipwrights on iron work. Accordingly, when the shipwrights were employed by the Glengall Iron Co., the boilermakers told the company that unless it terminated its at-will contract with the shipwrights, the boilermakers would walk off the job. Glengall complied with the defendants' demands. In a suit for interference with the shipwrights' prospective earnings from Glengall, the House of Lords held for the defendants. The court did not distinguish between interference with contracts terminable at will and

132 Id. at 956, 134 Eng. Rep. at 1179-80.

1ss Id. at 959, 134 Eng. Rep. at 1180. The court regarded the element of conspiracy as essential, as did the court in Temperton $v$. Russell. Judge Coltman stated that although the malicious act of one might be actionable, "it would be very difficult to infer such a motive from the insulated acts of one person unconnected with others." Id. at 959, 134 Eng. Rep. at 1180. The court in Temperton finessed the point; where a malicious conspiracy to deprive the beneficiary of an expectancy exists, the question of the liability of an individual actor need not be decided. 1 Q.B.D. at 729 (opinion of Lord Esher, M.R.). As the remarks of Judge Coltman suggest, the present importance of conspiracy is evidentiary only.

134 Under Epstein's account, no liability could be found, since the means of interference was not force or fraud. Epstein, supra note 40, at 49.

135107 Minn. 145, 119 N.W. 946 (1909).

${ }_{138} 1898$ A.C. 1 (H.L. 1897). Another case in this category is Mogul v. McGregor, 1892 A.C. 25 (H.L. 1891). It is revealing that both Bowen, L.J. in the Queen's Bench, and the House of Lords treated a plaintiff who complained that the defendants had driven him out of the tea trade with artificially low prices as having stated a prima facie case; the House of Lords's unanimous ecision for the defendants turns on the question of privilege. See 23 Q.B.D. 598, 613 (1889), 1892 A.C. at 57 (opinion of Lord Field) (all the judges' opinions concern principally whether the defendants' means of interference were within the bounds of fair competition). 
with expectancies, into which category it impliedly put the plaintiffs' interest. ${ }^{137}$ The court found that the defendants' conduct was protected by the right of free competition in labor. ${ }^{138}$ Where an interferor knowingly interferes with an expectancy in the exercise of his own right to offer his services, no liability attaches. ${ }^{139}$

In Tuttle, the plaintiff was a barber in a small village. The plaintiff alleged that the defendant, a wealthy banker in the village, set out to ruin the plaintiff's business by hiring barbers to set up a rival shop and by furnishing them with a shop rent-free in order to undercut the plaintiff's prices. The Supreme Court of Minnesota affirmed without opinion the lower court's denial of the defendant's demurrer. ${ }^{140}$ Judge Elliott, reporting the decision of the majority, voted to reverse on the ground that the complaint failed to allege that the defendant was intentionally running his business at a loss or that he intended to or did go out of business after the plaintiff was ruined, ${ }^{141}$ either of which would have proved that the defendant had no real commercial interest in the barber's trade. Elliott had no doubt, however, that an action would lie if the defendant were not acting in the exercise of his legal right to profit from the barbering business. ${ }^{142}$ Tuttle illustrates the proper meaning to be attached to malice in interference cases: malice is not the

1371898 A.C. at 21 (opinion of Hawkins, J.) ("[i]n the present case no contract was broken").

${ }^{138}$ The court analogized Allen to Mogul, where the defendants were protected by the right of free competition in trade. See, e.g., id. at 164 (opinion of Lord Shand). Regrettably, Allen uses the term "malice," whose definition as used there is unworkably vague. Since malice in the view of this comment is an amalgam of knowledge, a part of the prima facie case, and lack of commercial interest, it is difficult to interpret remarks such as, "No use of property which would be legal, if due to a proper motive, can become illegal because it is prompted by a motive which is improper or even malicious.' "Id. at 168 (quoting Bradford Corp. v. Pickles, 1895 A.C. 587 (H.L.)). If malice means evil intent, then this pronouncement contradicts the Gregory dictum. Since knowledge is regarded as implying intent (a person intends the natural and probable consequences of his acts at common law), and lack of commercial interest leads one to suspect an intent to injure, it is easy to see how knowledge plus lack of commercial interest is phrased as evil intent.

130 In Temperton, in contrast, the defendant had no interest in the expectancy interfered with and was held liable. See supra text following note 120.

14107 Minn. at 145, 119 N.W. at 946.

141 Id. at 151, 119 N.W. at 948 (Elliott, J., dissenting).

${ }^{142}$ [W] hen a man starts an opposition place of business, not for the sake of profit to himself, but regardless of loss to himself, and for the sole purpose of driving his competitor out of business, and with the intention of himself retiring upon the accomplishment of his malevolent purpose, he is guilty of a wanton wrong and an actionable tort. In such a case he would not be exercising his legal rights . . . .

Id. Concededly, under the analysis proposed here the question of the defendant's commercial interest would properly belong in the answer, not in the complaint, and hence should not figure in the court's review of the denial of the defendant's demurrer. 
presence of malign intent, of which there was no lack in Tuttle, but the absence of a genuine commercial interest.

Where the interferor is unaware of the expectancy, courts consistently decline to impose liabilty. ${ }^{143}$ One such case is Rickards $v$. Sun Oil Co. ${ }^{144}$ The plaintiffs in Rickards owned businesses on an island off New Jersey. The defendant, for the purposes of his demurrer, admitted to having negligently crashed into the bridge that formed the only link between the island and the mainland, causing the plaintiffs to lose business. The court held for the defendant; the defendant owed no duty of care to the plaintiff, since the defendant could not reasonably have foreseen injury to the plaintiffs, thus negating proximate cause. ${ }^{145}$ Under Epstein's corrective justice account of tort law, such a limitation on liability for unforeseeable harms is merely ad hoc. ${ }^{146}$ Absent other considerations, if the defendant caused the harm, he should be liable if he has interfered with a protected right of the plaintiff; if no right has been infringed, no inquiry into the foreseeability of the harm is necessary. Following the analysis advanced in this comment, however, the court's reasoning makes more sense. The defendant had a duty to avoid harming the plaintiff's expectancy if and only if the plaintiff had a right in it, ${ }^{147}$ which depends in turn on whether the defendant had notice of the plaintiff's expectancy. If one substitutes "foreseen" for "foreseeable" in the definition of proximate cause, the result and analysis of Rickards are entirely consistent with the analysis set forth above.

\section{B. Contracts}

When an obligee enters into a contract with an obligor, he obtains an exclusive right to the obligor's performance. Like the pursuer of a wild animal who has significantly advanced towards capture, the obligee has materially advanced toward obtaining the obligor's performance and thereby has a right to acquire that performance, a right that is superior to a third party's right to advance his own commercial interest. Thus the second component of malice, lack of commercial interest of the interferor in the per-

14s See W. ProssEr, supra note $9, \S 130$, at 952 (intent to interfere ordinarily required, which would imply knowledge of the expectancy).

14423 N.J. Misc. 89, 41 A.2d 267 (N.J. 1945).

145 Id. at 94,41 A.2d at 269.

${ }^{148}$ See Intentional Harms, supra note 18, at 429-30 (in an analysis of a similar case, Byrd v. English, 117 Ga. 191, 43 S.E. 419 (1903), Epstein suggests that failure to find liability is grounded in a desire by the court to avoid crushing burdens for negligent conduct).

147 See generally Hohfeld, supra note 78, at 30-32. 
formance of the obligee, drops out, and the mental element required to establish interference with contract is mere notice of the contract.

Unlike the case of an expectancy, where notice of the contract has been given, a genuine commercial interest no longer confers a privilege. ${ }^{148}$ The famous case of Lumley $v$. Gye $e^{148}$ illustrates this proposition. The plaintiff had a contract obligating Johanna Wagner to sing exclusively at the Queen's Theatre during the spring season of 1852. The defendant, knowing of the plaintiff's contract, offered Miss Wagner a larger sum to abandon her first contract and sing at Covent Garden. ${ }^{130}$ The court found for the plaintiff without inquiring into the defendant's motives or interest in procuring the breach of the first contract. Liability was predicated on knowledge; "it must now be considered clear law that a person who wrongfully and maliciously, or, which is the same thing, with notice, interrupts the relation subsisting between master and servant . . . commits a wrongful act for which he is responsible at law."151

Where, on the other hand, the interferor has no knowledge of the contract, not even a negligent or criminal act that deprives the obligee of the benefit of his bargain will be actionable. ${ }^{162}$ Thus, where the defendant kills a policy holder of the plaintiff insurance company, no liability for the value of the policy exists. ${ }^{153}$ In the well-known case of Byrd $v$. English, ${ }^{154}$ the defendant's workmen negligently damaged the plaintiff's electric lines, causing an interruption in the operations of plaintiff's plant. The court found for

${ }^{248}$ The presence of ill will on the part of the interferor towards the obligee to a contract is irrelevant. For example, in South Wales Miners' Fed'n v. Glamorgan Coal Co., 1905 A.C. 239 (H.L.), the defendant, a coal miners' union, induced its miners to abstain from working on certain days. The miners' wages were tied to the price of coal, which the defendant sought to elevate by reducing the amount of coal mined. The trial judge found that the defendant was motivated solely by an honest desire to help its workers, and not by any ill will towards the plaintiffs. Id. at 240 . In finding for the plaintiffs, Lord James held the absence of ill will and the presence of an interest in the subject matter of the contract to be irrelevant. "The fact that [the defendant's] motives were good in the interests of those they moved to action does not form any answer to those who have suffered from the unlawful act." Id. at 252 .

1192 El. \& Bl. 216, 118 Eng. Rep. 749 (Q.B. 1853).

130 The full facts were set out in Lumley v. Wagner, 1 De G., M. \& G. 604, 42 Eng. Rep. 687 (Ch. 1852) (suit in equity to enjoin Wagner from singing at the defendant's theater).

${ }^{151} 2$ El. \& Bl. at 224, 118 Eng. Rep. at 752-53 (emphasis added). The court's use of the term "relation" reflects the roots of the cause of action in the Statute of Labourers. See generally supra notes 1-4 and accompanying text.

152 See W. ProssER, supra note 9, § 129, at 941.

1s2 Mobile Life Ins. Co. v. Brame, 95 U.S. 754 (1877).

184117 Ga. 191, 43 S.E. 419 (1903). 
the defendant on the grounds of remoteness of damages, ${ }^{165}$ as did the court in Rickards. ${ }^{186}$ Under the present analysis, lack of liability follows directly from the fact that the defendant had no notice of the plaintiff's contract. ${ }^{167}$

\section{ConcLusion}

The law recognizes two intermediate stages of property rights in both the pursuit of wild animals and the acquisition of performance. The first is marked when a party begins pursuit or commences trade. The law grants a right good against the world to free pursuit, subject to a privilege in others similarly interested to pursue the animal or the performance. The acquisition of such a right, as with the perfection of rights in other species of incorporeal property, depends on notice being given to third parties of the pursuer's intent to exclude. The second stage is marked by the pursuer's having obtained some definite degree of physical control over an animal or having entered into a contract. At this stage, although the pursuer or obligee has acquired no property right in the thing itself, he has acquired an exclusive right to pursue, depriving other pursuers of the privilege of pursuit or commercial interest.

This analysis accounts for several inadequacies in prior discussions of interference torts. ${ }^{158}$ First, malice, divided into its constituent elements of notice or knowledge and lack of commercial interest, remains the center of the prima facie case, consistent with a corrective justice explanation. Second, the unified treatment of the law of interference with contracts, in which the obligee has and retains rights against the obligor, and of interference with expectancies, in which he has none, is the consequence of looking not at the prospective rights of the pursuer in the object of pursuit but at his current rights against other pursuers to free pursuit of performance, which in both cases is not yet obtained. Finally, this analysis accounts for the fact that the damages in tort for interference exceed those recoverable against either the obligor in contract or the prospective performer; although the proximate consequence of the interference is a loss of the performance sought, for the value of which the pursuer may recover, the right interfered with is the

\footnotetext{
${ }^{185}$ Id. at 194-95, 43 S.E. at 421.

${ }^{156}$ See supra notes 144-47 and accompanying text.

${ }^{157}$ See supra notes 146-47 and accompanying text (discussing proximate cause).

${ }^{158}$ See supra notes 18-54 and accompanying text.
} 
right to pursue, which is wholly distinct from the rights afforded by contract law to the obligor against the obligee.

Benjamin L. Fine 